\title{
The creativity of the J3K version of the Gojek advertisement in the Covid 19 pandemic era
}

\author{
Kania Untari Salsabila ${ }^{\mathrm{a}, 1, *}$, Naila Waliya Hamima ${ }^{\mathrm{b}, 2}$, Jamiatin $\mathrm{KN}^{\mathrm{b}, 3}$ \\ ${ }^{a}$ Communication Science Muhammadiyah University, Jl. K.H. Ahmad Dahlan, Cireundeu, Kec. Ciputat Tim., Kota Tangerang Selatan, Banten 15419 \\ ${ }^{1}$ kaniauntari01@ gmail.com*; ${ }^{2}$ kaniauntari01@gmail.com; ${ }^{3}$ jamiati.kn@umj.ac.id \\ * corresponding author
}

Article history

Received 09-11-2021

Revised 10-11-2021

Accepted 11-11-2021

Keywords

Covid-19

Creativity

Advertisement

\begin{abstract}
In the middle of the covid pandemic people are required to stay at home and also sosial distancing, according to government policy about transportation control made gojek provide a new service namely J3K. The purpose of this research to analyze the creativity of gojek advertisement both in terms of appearance and content. To make customer feeling more safe and comfortable, in creative way to promote their service they use an animation for advertisements. In this case researcher uses a case study approach with qualitative and descriptive for describe, analyze, and interpret the J3K Gojek advertisement. The result of this search based on observation, literature study (books, journals, and websites), and documentation, Gojek succeeded get the attention of the public from their creativity advertisement can gather the trust of their users especially the Indonesia citizen.
\end{abstract}

This is an open access article under the CC-BY-SA license.

\section{Introduction}

Indonesia and the rest of the world are experiencing this hard time because the covid pandemic that occurred in indonesia in early March showed positive cases that continued to increase every day (Zhong et al., 2020). Due to increasing number of covid cases, the government issued a policy, namely PSBB (Large Scale Social Restictions), in which the policy changed the order of human life in all fields from education, business, marketing to advertising (Darke \& Ritchie, 2007).

The actors in the industry are required to adapt to these circumstances, and must be able to take innovative and creative steps. For example in the business industry, business people must continue to rack their brains so that their business can survive weel, without reducing employees, deferring salaries, and much more (Cortegiani, Ingoglia, Ippolito, Giarratano, \& Einav, 2020). They must be able to market their products well, starting in terms of product quality and marketing. Which is where currently marketing can be done through various things, can be on social media, advertising, therefore from a marketing point of view this must be made creative and attractive so that many audiences are interested. Moreover, with the emergence of technology nowadays being a part of people's own lives, almost all aspects of life require modern technology. This modern internet-based technology makes it easier for humans to access various information, social media information is well packaged, to attract the attention of the public (Syafrida \& Hartati, 2020).

One of them is an advertisement, current advertisements can be found in various mass media. Unlike in the past, which could only be found on billboards or banners. Advertising has several functions, namely information by communicating product information, providing characteristics with location, persuasive function, by trying to persuade, and persuading consumers to consume certain information so as to change consumer attitudes towards the product (Wallace, Wladkowski, Gibson, \& White, 2020). To realize the function of the advertisement, the delivery of the 
advertisement must be innovative and not monotonous in terms of delivering dialogues, messages and much more. One form of creative advertising can be seen in Gojek advertisements, previously GoJek was also well known for its good image in making creative and innovative advertisements, because of this, GoJek received a positive response from various people (Syaipudin, 2020).

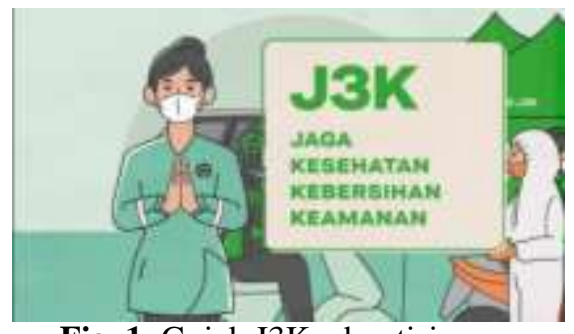

Fig. 1. Gojek J3K advertising

One example, in the advertisement for the J3K Gojek service, this advertisement began, when the PSBB in Jakarta in several existing service areas on motorbikes such as Goride could not operate, but services such as Gocar and Gobluebird could still operate but with a two-passenger limitation. As quoted on CNBC Indonesia (Hossain et al., 2020). This rule is contained in the Decree of the Head of the DKI Jakarta Provincial Transportation Service Number 105 of 2020 concerning Control of the Transportation Sector for the Prevention of Covid 19 During the Transition Period Towards a Healthy, Safe, and Productive Society. This regulation was signed on June 5, 2020. "It is not permitted to operate in areas that are implemented as tight control areas on a local scale," wrote the regulation as quoted on Monday (8/6/2020) (San, Atikno, \& Suratno, 2020).

With this, some motorcycle taxi partners were confused because the Goride service could not operate and could only deliver food or packages, which made some of the Gojek partners' income decreased (Azzuhri, Syarafina, Yoga, \& Amalia, 2018). This is where the Gojek company came up with an idea of how to continue operating amid the current Covid. J3K is a policy made by motorbikes to ensure that passengers feel safe driving with motorbikes (Andhini, 2017). This J3K Gojek service advertisement is made as attractive as possible, just like the previous Gojek advertisement using animation so that they don't shoot themselves where there will be lots of people crowding, the dialogue is very interesting and coupled with comedy in every scene, makes this ad less boring and entertaining for those who watch it. Viewed on YouTube Gojek itself, the response from the community is very positive, the message conveyed can also be immediately captured by the public (Widjaja, Astuti, \& Manan, 2019).

This advertisement has good creativity not only during a pandemic, J3K Ads have its own charm and the effectiveness of attractive advertisements as well, so that it makes the public or the public not only enjoy the advertisement but can also take the message that the Gojek service advertisement wants to convey (Rami, Abdullah, \& Simin, 2017). The J3K. The purpose of writing this journal is to find out how creative the J3K Gojek advertisement is during a pandemic like today. And to find out whether the Gojek ad this time is included in the creative advertising class, to increase the knowledge and insight of the author about advertising creative (Duffett, 2015).

\section{Theorotocal Framework}

\section{a) Advertising}

Advertising can be defined as "any paid form of non-personal communication about an organizational product service or idea by an identified sponsor". The purpose of being paid in this definition indicates that space or time for an advertising message, in general, must be purchased. The meaning of the word non-personal means mass media advertising such as a radio, TV, newspaper, a newspaper that can send messages to several groups of individuals at the same time. Advertising consists of several types following are some types of advertisements (Grewal, Bart, Spann, \& Zubcsek, 2016) :

First, inter-business advertisements, (advertisements between businesses are advertisements targeted at one or an individual who play a role in influencing the purchase of industrial goods or services for the benefit of the company where the individuals work), Secondly professional 
advertisements, professional advertisements are (advertisements targeted to professional workers such as doctors, lawyers, engineers and so on to encourage them to use the company's products in their field of work). Third, trade advertising, (advertisements targeting members who manage the marketing channel, such as wholesalers, distributors, or retailers). The purpose of such advertising is to encourage channel members to own, promote, and resell a particular brand of product to its customers (Shaouf, Lü, \& Li, 2016).

Effective and efficient advertising must have advertising objectives so that it is clear what advertising creative strategy will be made. Advertising goals or objectives are one of the initial foundations for creating an advertising creative strategy that later can know what to aim for. Without a purpose, the advertisement cannot be pursued and cannot convey what you want to convey with a clear purpose. As in the objective of the J3K Gojek advertisement, it increases awareness of the service in the GoJek, namely J3K (Oktafiandi, 2018).

\section{b) New Media}

New Media is the existence of new media such as the internet that can transcend the distribution pattern of traditional media messages, the interacting nature of the internet depicts geographical boundaries, capitalist interactions, and most importantly can be done in real-time (Watie, 2016). The presence of new media (new media / cyber media) makes information something that is easily searchable and open.

\section{New Media Function}

(Nasrullah, 2017: 3) The functions of new media, as so far obtained from traditional media, have also increased to be available on the internet. Among them: First, Media Television provides programs that aim to keep the audience entertained. Second, Youtube provides an alternative option to watch audio-visual shows that compete with these television programs (Lin, Venkataraman, \& Jap, 2013).

\section{New Media Characteristic}

There are several characteristics of youtube: (Fatty Faiqah, 2016) First, there is no limit to uploading videos. This is what distinguishes Youtube from other applications that have a minimum duration limit, such as Instagram, Snapchat, and so on. Second, the safety system is starting to be accurate. Youtube does not allow videos that contain Sara, illegal, and will ask questions before uploading videos. Third, Paid is currently viral everywhere, YouTube offers an offer for anyone who uploads a video to YouTube and a minimum of 1000 viewers will be given an honorarium (Theoldman, 2011). Fourth, the YouTube Offline System has a new feature for users to watch videos, namely the offline system. This system makes it easy for users to watch the video offline, but before that the video must be downloaded first. Fifth, a Simple Editor is available on the start menu to upload a video, users will be offered to edit the video first. The menu offered is to cut the video, filter colors, or add video transfer effects.

\section{c) Advertisisng Creativity}

according to (Morissan, 2015) "Creativity" is one of the most frequently used words in the advertising industry. Advertising is often referred to as "creative" only. The views on what is meant by creative advertising are not the same. One view is that creative advertising is an advertisement that can increase product sales. Another view says that creative advertising is an advertisement that comes from an idea, is original, has artistic and aesthetic value, and can win awards. Another opinion states that creative advertising is an advertisement that can affect the audience (Mujamiasih, Prihastuty, \& Hariyadi, 2013).

Some agree that creative advertising includes the following: First, the relevance of advertising is relevant to target consumers, contains information, and reflects the emotional desires consumers want when making a purchase or when trying a product so that it will influence purchasing decisions. Secondly Conformity, suitability means that the advertisement must provide information related to brands in one brand category (Lee \& Hong, 2016). Adequate advertising is also an integration or association of all message elements that are coherent and unambiguous to the target. The third is Newness, the new ad is unique, fresh, and unexpected. However, after all, creative 
advertising is not just about creating something unusual or strange, creative is an advertisement that must have a positive relationship with the target consumer (connectedness element) and provide information or reflect a brand positioning strategy (conformity element) (Rosengren, Eisend, Koslow, \& Dahlen, 2020).

\section{Method}

This study uses a qualitative descriptive method that focuses on efforts to describe, analyze, and interpret Gojek J3K advertisements from the youtube media (Kotler dan Keller, 2017). Through this method also obtained a variety of actual information about creativity in advertising. Data collection techniques used are observing, literature study (books, journals, and websites), and documentation. The analytical method used in this research starts from the stage of selecting advertisements, describing, analyzing, interpreting and evaluating and drawing conclusions (Ali Muhson, 2014).

\section{Results and Discussion}

Currently we are faced with a variety of advertisements in almost all media so that creative advertisements are needed so that people are interested in seeing these advertisements. Meaning and can influence emotions. As according to (Krishna, Cian, \& Sokolova, 2016). That creative advertising makes the audience pay attention to the ad in detail and detail. The following discusses the creation of Gojek Ads on J3K Services according to (Turner, 2018) through the scope of connectivity, conformity and novelty.

\section{a) Conectedness}

In this Gojek advertisement, it has a connection, this ad is relevant to what is being sought in today's society. That is, people currently need a lot of transportation to travel, but still feel afraid. because the covid virus is easy to transmit, so that for transportation such as the subway and KRL, people must be afraid to be in that place. By realizing the needs of the community, what really needs right now is the security or feeling safe in using public transportation, motorbikes can convince the public by guaranteeing that the're Gojek partners have implemented health protocols. This advertisement has the purpose of informing the public that currently Gojek has J3K services. So that there is no more fear in using online public transportation (Alamar \& Estruch, 2002).

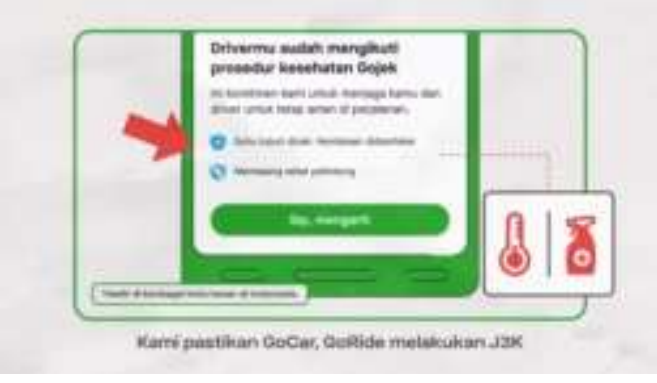

Fig. 2. Gojek J3K advertising

Gojek proves that it can provide a sense of security to the community by ensuring all partners carry out J3K, this makes people no longer fear when using a motorcycle taxi. The majority or as much as 86 percent of consumers considers the Gojek application to help them adapt and maintain productivity during the COVID-19 pandemic. On the other hand, 93 percent of consumers think the security of Gojek's services is better than industry standards.

These data are part of the latest research results from the Demographic Institute of the Faculty of Economics and Business, University of Indonesia (LD FEB UI) with the Gojek case study. The research was held on September 2020 through an independent survey, held online among 4,199 consumers who actively used Gojek in the past month. So consumer confidence in motorbikes cannot be separated from the initiative of the J3K protocol itself.

This is in accordance with the results of research conducted by Fellyta Oktaviana. S and Hartono Subagio, with the collection and sample methods, and the operational definitions of the variables 
contained. Endoser Credibility (X1), Advertising Creativity (X2), Advertising Effectiveness (Y1), Attitude Toward Brands (Y2). Found that advertising creativity on brand attitude has a significant relationship, this can be seen from the creative advertising design that will be able to foster positive attitudes from consumers. To show that consumer attitudes towards brands are directly influenced by the creativity of advertising messages received by consumers, also indirectly influenced by advertising through brand recognition, where through this brand recognition, consumers are familiar with brand criteria and help consumers to build attitudes towards brands. . (Fellyta Oktaviana. S, 2015)

\section{b) Suitability}

In this advertisement that in the midst of this pandemic, Gojek has J3K services, where this service makes the public no longer need to worry about using public transportation such as online motorcycle taxis, in the J3K advertisement gojek informs that before its partners come to serve customers, gojek first come to the J3K post to disinfect their vehicles, check the temperature, and ensure that the partners are in good health, so that they can deliver customers properly (Guisan, Thuiller, \& Zimmermann, 2017).

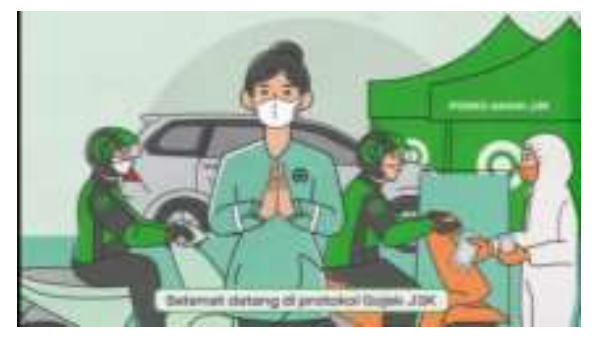

Fig. 3. Gojek J3K advertising

This advertisement is packaged in an attractive and innovative way, so that the message conveyed is clear, but not boring because every conversation that is accompanied by jokes is not contradictory and is still related to the information conveyed and does not cause ambiguity in providing information.

According to Wang (2006) the results of research conducted by Vincent Ekosaputra, Widayatmoko, with survey research methods and variable operations. Advertising Message Quality (X1), Advertising Creativity (X2), Advertising Attractiveness (Y), which can be concluded that the quality of advertising messages has a significant effect on advertising attractiveness. With the finding of the dimensions of attention related to paying attention to messages in advertisements as the highest dimension in influencing ad attractiveness.

\section{c) Renewability}

AIDA theory assumes, that the effect or the effect that hits someone after receiving an advertisement will go through 4 stages, namely attention, interest, desire, and action. If these three things did not materialize it would have been difficult for advertising to expect its products to be chosen by consumers. Therefore, novelty must exist in a creative advertisement in order to generate awareness and interest in the public (Shao \& Chen, 2016).

Like this J3K advertisement, it is very fresh, new and unique, the message to be conveyed is very much in line with public interest today, both in terms of advertisement appearance and content. Moreover, almost all Gojek advertisements give a positive response, they can be accepted by the general public. The ad, which lasts 1 minute and 18 seconds, starts with caravan music where in this music we can hear drums that bring new enthusiasm to the listeners so that they can pay more attention to the ad. 


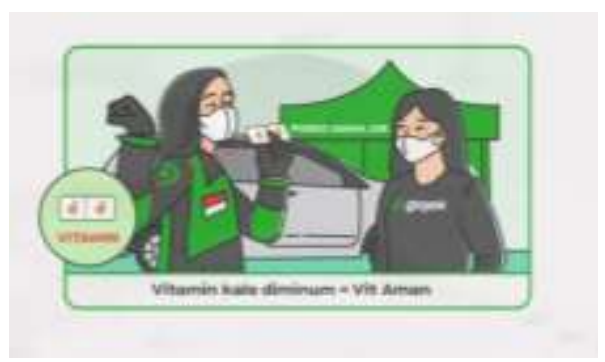

Fig. 4. Gojek J3K advertising

Followed by the first gojek protocol, namely "Keep Your Health", here the gojek provides vitamins to drivers who want to take passengers. In this scene the inner joke adds to the inner joke, which is "Vitamin if you drink it to be safe Vit" then there is a temperature check where there is also a conversation between the driver and the one who checks the temperature, namely "Why can't the temperature be set, the name is temper set" where jokes like this sound not stiff and funny makes this ad more interesting and unique.

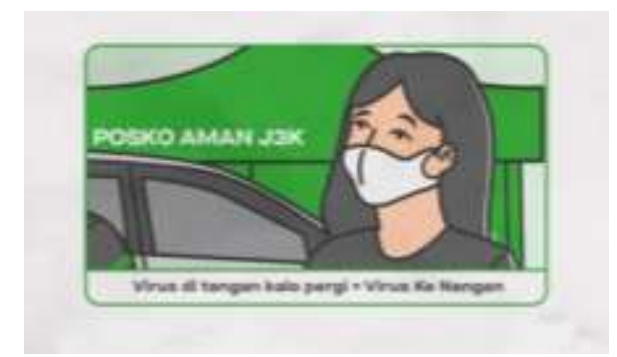

Fig. 5. Gojek J3K advertising

The video is continued with the second gojek protocol, "Keep Clean", in which the drivers wash their hands for 20 seconds, so that the drivers can avoid viruses that may be in their hands and the creativity of the gojek takes advantage of this scene with the comedy of today's troubled children, namely "If the virus is in hand, the name goes away (Nurhardian, Ferdiansyah, \& Dwiyatno, 2015). Virus to memory". Then there is the next cleanliness is the disinfection of the vehicle before the driver picks up passengers here. There is also an interesting conversation. "Germs, if you kill them, turn into germs." This scene is also quite relevant to the current situation. Disinfection they will die or the conversation was conditioned as a punishment.

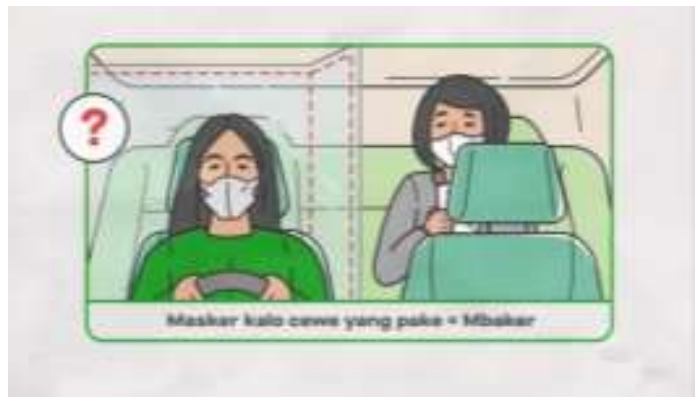

Fig. 6. Gojek J3K advertising

And the last J3K is "Keeping Security", which here gojek provides a protective barrier for drivers, both for cars and motorbikes. Do not forget the funny jokes accompanied by guessing guesses "if there are two names are two," followed by the next step, routinely changing masks and jokes with guess the same guess as before "mask if the girl is wearing a mbaker" (., Yanuarsari, \& Pratiwi, 2018).

Everything in the scene is explained one by one about $\mathrm{J} 3 \mathrm{~K}$ accompanied by animation, which practices its partners implementing the J3K protocol. So besides getting information, this ad can also be entertaining. That is why this advertisement has received a lot of positive comments from the 
public both in terms of the message or the way it is conveyed. Judging by the screenings, it has reached 7.3 billion and 18 thousand people who like this video plus all the positive comments from the public who always support Gojek in making creative advertisements, where the broadcast starts in June.

So when this ad appears when watching YouTube the audience pays less attention, but on the other hand, if this ad is boring when it just appears, it will definitely pay more attention and pay attention to the information the advertiser wants to convey (Baskoro, 2018). This can be concluded, because according to research conducted by Anita Chrishati Puteri Tito and Claudy Gabriella, who used exploratory research and depth interviews which examined the advertising factors that can attract viewers to watch Skip-Ads ads on YouTube until it's finished. With the results, some respondents with a relatively young age said that the ads that often appear are not attractive because they do not have a clear storyline. Ads only promote the same product and are known to be so that they do not attract further interest in watching advertisements, for adult respondents they are often not interested in watching these ads, because they are often considered weightless. Ads cannot provide anything meaningful either information or knowledge to the audience, so it is considered that watching advertisements are just a waste of time (Tito \& Gabriella, 2019).

\section{Conclusion}

Based on the things that have been described in the previous chapter, and to answer the purpose of writing this journal, it can be concluded that the Gojek advertisement version of the J3K service this time is a creative advertising class. Because according to Shimp \& Andrews (2013) creative advertising includes, connectedness, suitability, and novelty, the J3k version of the Gojek advertisement this time includes all three, which: First, the connection where this ad is relevant to what is needed by the community during the pandemic like this, namely safe transportation and implementing health protocols in it so that there is no longer any fear from the public about using public transportation today. Second, the suitability of the message conveyed by the J3K version of the Gojek advertisement this time, the message can directly reach the public because it is packaged in a very epic, interesting, and innovative way so that when the public hears it there is no more boredom in watching the ad. Third, the renewal of the J3K version of the Gojek advertisement this time can be said to be a fresh and unique advertisement, because it contains a unique message, and is also displayed unusually, moreover, this ad has received quite a lot of positive responses from various circles of society, the proof is that the ad it got quite a several viewers counted today.

\section{Acknowledgment}

The author would like to thank the Communication Studies program of the Faculty of Social and Political Sciences, Muhammadiyah University of Jakarta, Communication Science UAD for the opportunity given to the author to complete this paper through the 2020 Youth Communication program.

\section{References}

. M., Yanuarsari, D. H., \& Pratiwi, M. R. (2018). IKLAN LAYANAN MASYARAKAT DAN RESPON KHALAYAK. Islamic Communication Journal. https://doi.org/10.21580/icj.2017.2.2.2170

Alamar, M., \& Estruch, V. D. (2002). A contribution to fuzzy subspaces. Applied General Topology. https://doi.org/10.4995/agt.2002.2107

Ali Muhson. (2014). Teknik Analisis Kuantitatif. Makalah Teknik Analisis II.

Andhini, N. F. (2017). gojek. Journal of Chemical Information and Modeling.

Azzuhri, A. A., Syarafina, A., Yoga, F. T., \& Amalia, R. (2018). A Creative, Innovative, and Solutive Transportation for Indonesia with Its Setbacks and How to Tackle Them: A Case Study of the Phenomenal GOJEK. Review of Integrative Business and Economics Research.

Baskoro, A. P. (2018). Gaya Eksekusi Iklan Digital Studio Workshop Depok Melalui Poster. J-Ika. 
Cortegiani, A., Ingoglia, G., Ippolito, M., Giarratano, A., \& Einav, S. (2020). A systematic review on the efficacy and safety of chloroquine for the treatment of COVID-19. Journal of Critical Care. https://doi.org/10.1016/j.jcrc.2020.03.005

Darke, P. R., \& Ritchie, R. J. B. (2007). The defensive consumer: Advertising deception, defensive processing, and distrust. Journal of Marketing Research. https://doi.org/10.1509/jmkr.44.1.114

Duffett, R. G. (2015). Facebook advertising's influence on intention-to-purchase and purchase amongst millennials. Internet Research. https://doi.org/10.1108/IntR-01-2014-0020

Grewal, D., Bart, Y., Spann, M., \& Zubcsek, P. P. (2016). Mobile Advertising: A Framework and Research Agenda. Journal of Interactive Marketing. https://doi.org/10.1016/j.intmar.2016.03.003

Guisan, A., Thuiller, W., \& Zimmermann, N. E. (2017). Habitat suitability and distribution models: With applications in R. In Habitat Suitability and Distribution Models: With Applications in $R$. https://doi.org/10.1017/9781139028271

Hossain, M. M., Tasnim, S., Sultana, A., Faizah, F., Mazumder, H., Zou, L., .. Ma, P. (2020). Epidemiology of mental health problems in COVID-19: A review. F1000Research. https://doi.org/10.12688/f1000research.24457.1

Kotler dan Keller. (2017). Manajemen Pemasaran, Edisi 12, Jilid 1, PT.Indeks,. Jakarta. In $e$ - Jurnal Riset Manajemen.

Krishna, A., Cian, L., \& Sokolova, T. (2016). The power of sensory marketing in advertising. Current Opinion in Psychology. https://doi.org/10.1016/j.copsyc.2016.01.007

Lee, J., \& Hong, I. B. (2016). Predicting positive user responses to social media advertising: The roles of emotional appeal, informativeness, and creativity. International Journal of Information Management. https://doi.org/10.1016/j.ijinfomgt.2016.01.001

Lin, C., Venkataraman, S., \& Jap, S. D. (2013). Media multiplexing behavior: Implications for targeting and media planning. Marketing Science. https://doi.org/10.1287/mksc.1120.0759

Morissan. (2015). Periklanan: Komunikasi Pemasaran Terpadu. Jakarta: Prenada Media Group.

Mujamiasih, M., Prihastuty, R., \& Hariyadi, S. (2013). Subjective well-being (SWB): Studi indigenous karyawan bersuku Jawa. Journal of Social and Industrial Psychology.

Nurhardian, T., Ferdiansyah, R., \& Dwiyatno, S. (2015). Iklan Layanan Masyarakat Tentang Tertib Berlalu Lintas di Kota Rangkas Bitung dengan Menggunakan Adobe Premiere dan Adobe After Effect. Journal PROSISKO

Oktafiandi, I. (2018). Strategi kreatif iklan "kisah legenda nusantara" dalam menumbuhkan brand awareness indoeskrim nusantara. In Jurnal Visi Komunikasi.

Rami, A. A. ., Abdullah, R., \& Simin, M. H. A. (2017). Influence of Leadership in Rural Community Development in the State of Terengganu, Malaysia. Ajps.

Rosengren, S., Eisend, M., Koslow, S., \& Dahlen, M. (2020). A Meta-Analysis of When and How Advertising Creativity Works. Journal of Marketing. https://doi.org/10.1177/0022242920929288

San, S., Atikno, W., \& Suratno, S. (2020). Analisis diskriminan faktor kecemasan karyawan menghadapi dampak Pandemi Covid-19: Kasus perusahaan manufacturing dan jasa survey. Operations Excellence: Journal of Applied Industrial Engineering. https://doi.org/10.22441/oe.2020.v12.i2.006

Shao, L., \& Chen, G. Q. (2016). Renewability assessment of a production system: Based on embodied energy as emergy. Renewable and Sustainable Energy Reviews. https://doi.org/10.1016/j.rser.2015.12.063

Shaouf, A., Lü, K., \& Li, X. (2016). The effect of web advertising visual design on online purchase intention: An examination across gender. Computers in Human Behavior. https://doi.org/10.1016/j.chb.2016.02.090

Shimp, T. A., \& Andrews, C. J. (2013). Advertising, promotion, and other aspects of integrated marketing communication. In Integrated Marketing communications.

Syafrida, S., \& Hartati, R. (2020). Bersama Melawan Virus Covid 19 di Indonesia. SALAM: Jurnal Sosial Dan Budaya Syar-I. https://doi.org/10.15408/sjsbs.v7i6.15325 
Syaipudin, L. (2020). Peran Komunikasi Massa Di Tengah Pandemi Covid-19. Kalijaga.

Tito, A. C. P., \& Gabriella, C. (2019). Faktor-faktor Iklan yang Dapat Menarik Penonton Untuk Menonton Iklan Skip-Ads di Youtube Sampai Selesai. Jurnal Akuntansi Maranatha. https://doi.org/10.28932/jam.v11i1.1544

Turner, T. S. (2018). THE SOCIAL SKIN. In Reading The Social Body. https://doi.org/10.2307/j.ctt20h6vbr.5

Wallace, C. L., Wladkowski, S. P., Gibson, A., \& White, P. (2020). Grief During the COVID-19 Pandemic: Considerations for Palliative Care Providers. Journal of Pain and Symptom Management. https://doi.org/10.1016/j.jpainsymman.2020.04.012

Wang, A. (2006). Advertising engagement: A driver of message involvement on message effects. Journal of Advertising Research. https://doi.org/10.2501/S0021849906060429

Watie, E. D. S. (2016). Komunikasi dan Media Sosial (Communications and Social Media). Jurnal The Messenger. https://doi.org/10.26623/themessenger.v3i2.270

Widjaja, A., Astuti, W., \& Manan, A. (2019). The Relationship between Customer Satisfaction and Loyalty: Evidence on Online Transportation Services in Indonesia. International Journal of Advances in Scientific Research and Engineering. https://doi.org/10.31695/ijasre.2019.33166

Zhong, B. L., Luo, W., Li, H. M., Zhang, Q. Q., Liu, X. G., Li, W. T., \& Li, Y. (2020). Knowledge, attitudes, and practices towards COVID-19 among chinese residents during the rapid rise period of the COVID-19 outbreak: A quick online cross-sectional survey. International Journal of Biological Sciences. https://doi.org/10.7150/ijbs.45221 